\title{
Obstacles to Political Development in the Post-Tablian Period in Afghanistan: An Analytical Study
}

\author{
Farhad Sultani \\ Professor Assistant at Faculty of Public Policy and Administration, Balkh University and PhD Scholar at Mangalore University \\ Email: farhadsultani782@yahoo.com \\ Eraj Haidari \\ Professor Assistant at Faculty of Law and Political Science, Balkh University \\ DOI: 10.29322/IJSRP.10.09.2020.p10599 \\ http://dx.doi.org/10.29322/IJSRP.10.09.2020.p10599
}

\begin{abstract}
After the Second World War, political development has become the core topic of political science and sociology studies and interestingly, several studies indicated that political development positively had affected on the socio-economic development of developing nations. his section outlines the proposed methodology for the study. The present study is designed to identifies the key obstacles facing political development in the context of Afghanistan between 2001 to 2018. This study is planned as a qualitative method and based on available literature review. Keeping in view the nature of research of the problem and question, the efforts have been made to collect material from diverse sources. Thus, there is a combination of primary and secondary sources. Information will be collected from documents such as the International agencies organization, books, journals, speeches, statements and official declarations and communications. The findings of this paper show that the lack of security, poor economic, lack of political commitment, ineffective governance, highly centralized government, political instability, and more importantly rampant corruption is the main obstacles to political development in the context of Afghanistan in the Post-Taliban period. Moreover, political development has not taken place properly in the postTaliban administration. last but not least the result of this study will be fruitful to the present and future government of Afghanistan in order to find out possible solutions to the political development.
\end{abstract}

Index Terms- Politic Development, Afghanistan, Security, Corruption, Development.

\section{INTRODUCTION}

P olitical thinkers and economic scholars have different points of view on political development. It is the belief of this study that there is no broad consensus about political development among social scientist so far. The literature review shows that political development is prerequisite for the economics growth, increasing popular participation and building up the government capabilities of developing countries. Today, Urbanization, a shift of the population from a rural to an urban society, is an outcome of social, economic, and political developments that lead to immense pressure on the natural and built environment. Whereas
Afghanistan is a traditional and complex society to govern with so many ethnic classes. William Maley (2011) stated that despite rampant corruption and insecurity, Afghanistan encounters with number of problems including poor governance, lack of popular participation in macro-issues (elections), shortage of political instability, real conflicts of interest, and parallel and potentially conflicting systems of authority, nepotism, and these problems have affected the path of political development in the context of Afghanistan. Ben Smith (2011) stressed that the centralization of political power and administrative authorities and the ineffective public sector organizations are considered to be the key obstacle to political development in the Post-Taliban period in Afghanistan. In addition to this, he further states that the president has broad powers under the Constitution, being commander-in-chief of the Afghan armed forces and empowered to inaugurate the parliament and power is limited only in Kabul. The significance of the study lies in providing the framework of political development in Afghanistan, formulating a democratic fabric and evaluating the governance capabilities of the Afghan society. This will help policy makers in addressing the challenge in order to make a conducive environment for political stability and political development in Afghanistan. It may be made clear here that it does not provide an in depth analysis of various factors and forces. Instead, provides synoptic view of various issues and problems related to political development. It is expected that the results of this work would not only facilitate the scholars and experts of politics and civil society activism but it would be also a massive contribution for the students, and policymakers in the field of development studies.

The questions that will be addressed in this study to: How far is Afghanistan from the political development process? what the problems to political development road in Afghanistan. This study is designed to assess the obstacles facing the political development in the post-Taliban period in Afghanistan and provide some possible solutions for the present government in order to cope up with problems that bedabbled the path of political development in Afghanistan.

\section{CONCEPTUAL FRAMEWORK}

Before discussing the issue of political development, this study concisely outlines the meaning of development and what 
development is all about then it will help readers to understand better the political development. There are as many definitions for political development as number of economic thinkers but some key definitions are illustrated as follows: Development means "a specified state of growth or advancement; a new and advanced product or idea; an event constituting a new stage in a changing situation." (Oxforddicationaries.com) The term political development like other concepts of political science has a lack of consensus among researchers and scholars. It must be acknowledged that the term "political development" is relatively novel to political science. According to Lucian W. Pye and Sidney Verba (2015) for many people political development means primarily the prerequisite political environment essential for economic and industrial development. In sum, political development has been subsumed in the literature concerned with state-building and with democratic transitions (Fukuyama, 2004; Maley, 2006).

\section{OBSTACLES TO POLITICAL DEVELOPMENT IN AFGHANISTAN}

Obstacles to political development in the context of Afghanistan is a controversial and complex issue. There many barriers facing the political development road in Afghanistan including the problem of drugs, the situation of women, poverty, political and administrative corruption, and cultural problems and the inadequacy of the media, insecurity, religious extremist values and more importantly, unfinished ethnic conflict. Despite the fact that in contemporary Afghanistan, various measures have been taken by various political currents for the political development of this country, but so far, no good record has been presented in this regard. It seems that there are various obstacles to political development, and ethnicity is the most important challenge to political development.

1.1 Poor governance as a main problem to the political development road in Afghanistan:

"Good governance implies presence of rule of law, safeguard of human rights, and existence of honest and efficient government, accountability, transparency, predictability and openness" (Pierre Landellmills and Ismail Serageldin,1991). Whereas lack of good governance can be remarked as main problem to political development in Afghanistan. In addition to this, several political and economic commentators believe that rebuilding political institutions in developing nations in general and particularly in Afghanistan is extraordinary difficult task, for which the government of developing nations require considerable and sustainable amount of technical and financial foreign aid for the period of time (Chris Johnson, William Maley, 2003).

1.2 Corruptions as main problem to political development:

Insecurity, corruption, narcotics and poverty have been considered the main problems in the post-Taliban period in Afghanistan. Meanwhile, the phenomenon of "corruption" is a serious threat to Afghanistan; Because a large part of the insecurity, the increase in cultivation and production of narcotics and the slowness in improving the economic situation and livelihood of the people, is due to corruption. There is no doubt that corruption is a global issue and no society can be safe from corruption and its consequences. Several studies indicate that corruption is the single greatest obstacle to economic and social development around the world. Every year $\$ 1$ trillion is paid in bribes while an estimated \$2.6 trillion are stolen annually through corruption a sum equivalent to more than 5 per cent of the global GDP. Shortly, corruption is perceived the main barrier to political development in the context of Afghanistan. widespread corruption adversely affected governance quality, can fuel organized criminal networks and promote crimes such as human trafficking, arms and migrant smuggling, counterfeiting and the trade in endangered species in the country.

3.3 Centralization of political and administrative power in Kabul can be considered as main obstacle to political development

The economic system, quality of life, educational set up, healthcare sector and political process has significantly changed after the removal of the Taliban from the power in Afghanistan but there are many challenges, including lack of political set, poor governance, fragile economic system, corruption and so forth. Ivan Safranchuk (2017) stressed that centralized political set up in Afghanistan not only greatly intensifies the political competition but also increases the cost of holding the country together.

\subsection{Misunderstanding of political development among political elites}

Review of literature indicated that political development is a more elusive among political elites in the context of Afghanistan. The meaning and the conceptualization of development was greatly influenced by the ideological contradiction between the western educated and scholastic scholars. Western educated believe that political development plays very crucial for promoting democracy, human rights, good governance, citizens participation in public affairs and more precisely democratic Afghanistan, in contrast, scholastic scholars perceived or considered the political development as threat to indigenous values in Afghanistan and they posed number of challenges the road of political development. The concept of political development has not been internalized among Afghan political leaders and more precisely warlords strongly reject the political development in Afghanistan and they believe political development is more western oriented.

3.5 lack of citizens trust seems as main obstacles to political development

The erosion of confidence between the government and citizens is a systematic of a deeper challenge, rather than the problem itself. Today Afghan people despite multiple reasons are losing their faith in government. The growing trust deficit between the people and the government, particularly on governance, rule of law and the economy as well as public service delivery is still in very high scale. All in all, trust of people is the greatest social capital for the strengthening the road of political development in developing nations in particular Afghanistan. In contrast, today lack of trust in government is a major threat.

1.4 lack of national identity in Afghanistan,

This publication is licensed under Creative Commons Attribution CC BY.

http://dx.doi.org/10.29322/IJSRP.10.09.2020.p10599

WWW.ijsrp.org 
Without a national identity, speaking of political development is undoubtedly an exaggerated and baseless claim. A society will never be able to achieve political stability and development until it reaches the stage of formation of national identity and does not go through the structures and ideas of prenationalization. Acquisition of national identity and manifestation of national will and desire are considered as the primary and basic signs of political development in any country.

\section{5 lack of unified consensus among Afghan leaders on} political development,

Review of literature stated that one of the important challenges in the path of political development of Afghanistan is the lack of public consensus among the diverse population of this land. However, after the fall of the totalitarian rule of the Taliban, the conditions were created for the tribes and inhabitants of this land to move towards a grand consensus in an atmosphere away from war and tension. But unfortunately, after a short time, the political and managerial process of the country returned to its former orbit.

3.6 Imbalance of resource distribution in Afghanistan

The imbalance in the implementation of development projects and the allocation of budgets is the main problem to political development in Afghanistan. For example, in certain districts and provinces, due to special tendencies, despite the lack of public acceptance of the reconstruction process or the domination of the opposition in those areas, it is tried that international aid and development programs are drawn and allocated to those areas at any cost.

\subsection{Lack of security as main challenge to political development}

Lack security is the greatest challenge to the road of political development in Afghanistan. majority people in Afghanistan claim that murder cases, target killing, and armed robberies almost every night across the country is rising.

According to Thomas Hobbes (1996), security is the core responsibility of the state. The primary purpose of government is to provide security and welfare to its people. Unfortunately, the Afghan government has failed to provide a secured and safe environment for lives, properties and the conduct of business and economic activities. The alarming level of insecurity in Afghanistan has fueled the crime rate and terrorists' attacks in various parts of the country, leaving unpalatable consequences for the nation's economy and its growth. Most of commentators and scholars who have research and studied about the insecurity causes in Afghanistan demonstrated that despite many attempts, the level of insecurity in the country is very still high, and a confirmation of this is the low ranking of Afghanistan in the Global Peace Index.

Almost 19 years have passed since the removal of the Taliban from the power, but peace remains great dream for every Afghan-individual in Afghanistan and persisting insecurity continued to be the main challenges to the political development and as well as to the stabilization efforts in Afghanistan.

\subsection{Socio-cultural barriers to the political development}

Afghanistan was always divided into distinctive communal, ethnolinguistic, and religious groups. Moreover, these groups possessed a social system that emphasized loyalty to the local social group (qawm) rather than a higher-order abstraction like the state. The geographical barrier set by the Hindu Kush Mountains created a barrier between Kabul and the rural areas and retarded the development of centralized political institutions, which could only expand in power at the expense of local loyalties (Larry Goodson,).

3.9 Ethno-religious conflicts as key challenge to political development

Today ethno-religious conflict is the main source of problem in Afghanistan and it adversely affect on the process of political development. thus, the new political system propped up by Washington and its allies aimed to balance ethnic relations and prevent a renewed conflict by ostensibly attempting to make the new political system more representative, open and a level playing field for all Afghans. Some of the past discrimination against certain minorities was abandoned. However, the centralized system failed to deliver governance at subnational level.

Some of these critical shortcomings were papered over by more informal means, such as elite alliances and patronage politics, which serviced those in power but delivered little in the way of political stability and development.

A big part comprised of deal-making, in which appointments to key posts amounted to a distribution of political spoils. This went against the demands of many Afghans, who called for a meritocracy and for transparency (Siddique, 2012).

3.10 Lack of strong political parties as key barrier to political development

In the absence of strong pluralistic and democratic institutions to mediate internal tensions, political bargaining and the competition for power will most likely continue to occur outside the institutions of government. Because of their past shortcomings, however, many Afghans regard political parties with suspicion. Yet, post-Taliban Afghanistan has witnessed the emergence of many small democratic parties that offer a break with this past, and the means to create a stable and democratic parliament. And many Afghans, especially young people, now recognize parties as an essential component of the legal democratic process.

\section{RESULT}

One of the important political and social issues that is widely discussed today and discussed in scientific and political forums is the issue of political development. The past three decades of war and disorder have had a devastating impact on the Afghan people. Millions have been killed, millions more have been forced to flee their homes and the country's infrastructure and forests have all but been destroyed. The social fabric of the country is fractured and state institutions are fragile and weak.

William Maley (2011) in his paper entitled "Challenges of Political Development in Afghanistan: Mass, Elite and Institutional Dimensions" states that despite insecurity and corruption, Afghanistan suffers from number of other challenges such as the trust deficits, real conflicts of interest, and parallel and potentially conflicting systems of authority, nepotism and 
poor governance, have affected the path of political development in the context of Afghanistan.

Development's policies are based on a set of premises: statebuilding, state of law, democratization, accountability and privatization. The idea is that the political development could be implemented through the 'civil society' of the building from scratch of new institutions. Such a model works when there is political will from the local political authorities and the society to adopt such a model. But in any case, a policy of development should be based on political legitimacy. the result of this paper indicates that political development has not taken place in Afghanistan and there are many challenges facing the political development in Afghanistan.

\section{CONCLUSIONS}

There are various perceptions regarding According to some researchers, political development is the political methods and policies that facilitate economic growth in developing countries. Other scholars have focused on the political development of new regimes, the expanded role of governments, increasing political participation, and the ability of regimes to maintain order in the face of rapid change, as well as competition between political groups, classes, and ethnic groups. They define power as well as competition in social status and wealth. For others, political development is how revolutions take place, especially the conditions for the replacement of capitalist or socialist systems.

In sum, there are many reasons why actualizations of political development is unproductive and the government failed to hold accountable for the citizens and donor community. Despite all these, foreign aids are only conditional on Afghanistan agreeing to accountable, effective, transparent, sound public sector organizations and as well as to implement a reliable anticorruption strategy that is in accordance with law.

\section{RECOMMENDATION}

There is a clear consensus that political development is indispensable for socio-economic and cultural betterment of Afghanistan. political development promotes the institutions, judicial, administrative, economic, and social rules and protection of human rights, respect of the rule of law, and ensure that people are free to participate in those issues that affect their lives.

- In fact, political development is essential prerequisite for any country's development and to make the state and the political system workable and suitable for the people.

- To bring political development in Afghanistan different government organization should empower economic, social and political development in networked way, by making healthy communication from top to bottom accordingly in hierarchy of the power distribution.

- International and national actors should work together on the curtail of challenges of political development in the context of Afghanistan by providing different research, advocacy, consulting ensuring accountability, rule of law, and transparency of different government organs.

- Empowering different stakeholders for instance civil societies, political parties, governmental and nongovernmental institutions, pertinent to Promoting the indigenous values identified with governance practices in Afghanistan.

\section{REFERENCES}

[1] Hobbes, T. (1996). Leviathan, edited by J. C. A. Gaskin (Oxford: Oxford University Press, pp. 104

[2] Johnson, C., Maley, W., Thier, A., \& Wardak, A. (2003). Afghanistan's political and constitutional development. Department for International Development

[3] Maley, W. (2011). Challenges of political development in Afghanistan mass, elite and institutional dimensions. International Studies, 48(1), 21-41.

[4] Maley, W. (2011). Challenges of political development in Afghanistan mass, elite and institutional dimensions. International Studies, 48(1), 21-41.

[5] Maryam ,Karimi, \& Singh, S. (2014). Political Development Concept by Looking Briefly at the Iran"e Mohammad Reza Pahlavi Rule. Journal of Public Administration and Governance, 4(4), 67-78.

[6] Pierre Landellmills and Ismail Serageldin, "Governance and the external factor," World Bank Economic Review (1991): 303-320

[7] Pye, L. W., \& Verba, S. (2015). Political culture and political development. Princeton University Press.

[8] Siddique, A. (2012). Afghanistan's ethnic divides.

websites

[1] http://www.outlookafghanistan.net/topics.php?post_id=26842

[2] http://www.politicalsciencenotes.com/articles/stages-and-problems-ofpolitical-development $/ 580$

[3] https://www.oxfordreference.com/view/10.1093/oi/authority.201108031003 34639

[4] http://www.hubcymru.org/images/user/Hub\%20What\%20is\%20Developme nt.pdf

[5] http://www.yourarticlelibrary.com/political-science/six-models-ofdevelopment/40382

[6] https://www.scribd.com/presentation/419444603/Todaro-s-ThreeObjectives-of-Development

[7] https://www.crisisgroup.org/asia/south-asia/afghanistan/political-partiesafghanista 